\title{
PROGRESSIVE TAXATION OF PERSONAL INCOME IN UKRAINE
}

\section{ПРОГРЕСИВНЕ ОПОДАТКУВАННЯ ДОХОДІВ ФІЗИЧНИХ ОСІБ В УКРАЇНІ}

\author{
Mendzhul K.V., Student of the Faculty of Law \\ Chernihiv National University of Technology
}

Shevchenko Yu.V., Senior Lecturer in the Specific Purposes Department

Chernihiv National University of Technology

The article analyzes the legal problems of implementation of progressive taxation of personal income in Ukraine. The relevance of the research is due to the fact that the current taxation system in Ukraine needs to change the form of taxation to that one which will take into account the share of income of the state population and establish taxes at the level of opportunities of the citizens of the country, that is, the implementation of progressive taxation.

The purpose of the article is to determine the nature of progressive taxation of personal income and possibility of introducing such form of taxation in Ukraine: the origin of the tax system of Ukraine and the content of the concept of progressive taxation were outlined, foreign experience of progressive taxation of personal income was studied, the main legal problems of such form of taxation were determined.

Progressive taxation is a widespread form of taxation around the world. For Ukraine implementation of a progressive tax scale is not novelty, as this form of taxation had been operated in the country by 2004 , and over time it was changed to another form, which nowadays is a heavy burden for the population of Ukraine.

It has been found out that progressive taxation means higher tax rates for those with higher income and lower rates for those who have lower income. The main purpose of the progressive tax scale is to reduce the social inequality of the citizens.

It has been determined that progressive taxation has both positive and negative aspects of its existence in Ukraine. The positive ones are the following: the existence of a correct distribution of tax burden; reducing the pressure on people with low-income; balancing of the domestic tax system with the tax legislation of the European countries. The main negative side is the creation and operation of illegal schemes, tax evasion and loss of initiative to work and earn higher income.

It has been mentioned that nowadays there is a bill of Verkhovna Rada of Ukraine aimed at introducing a fair progressive scale of personal income tax. The main goals of the draft law and the possibilities of its implementation have been outlined.

As a result of the research, the authors have come to the conclusion that Ukrainian current tax system needs to be changed by implementing progressive taxation to improve the economic level of life of the population.

Key words: system of taxation, income, personal income tax, progressive taxation, progressive tax rate.

У статті аналізуються правові проблеми встановлення прогресивного оподаткування доходів фізичних осіб в Україні. Актуальність теми дослідження зумовлена тим, що сучасна система оподаткування в Україні потребує зміни форми оподаткування на ту, яка буде враховувати частку доходу населення держави й установить податки на рівні можливостей громадян країни, тобто впровадження прогресивного оподаткування.

Мета статті - визначення сутності прогресивного оподаткування доходів фізичних осіб і можливості запровадження такої фоорми оподаткування в Україні: зазначено історію існування податкової системи України, зміст поняття прогресивного оподаткування, досліджено зарубіжний досвід прогресивного оподаткування доходів фізичних осіб, визначено основні правові проблеми існування цієї форми оподаткування.

Прогресивне оподаткування є розповсюдженою формою оподаткування в різних країнах світу. Для України встановлення прогресивної шкали оподаткування не є новизною, адже до 2004 р. в державі функціонувала саме ця форма оподаткування, 3 часом вона була змінена на іншу, яка сьогодні є важким тягарем для населення.

Установлено, що прогресивне оподаткування означає більш високі ставки податку для тих, хто має більший дохід, і менші ставки для тих, хто має низький дохід. Основною метою прогресивної шкали оподаткування є зменшення соціальної нерівності громадян країни.

Визначено, що прогресивне оподаткування має як позитивні, так і негативні сторони свого існування в Україні. До позитивних можна зарахувати існування правильного розподілу податкового навантаження; зменшення тиску на осіб, які мають низький рівень доходу; гармонізація вітчизняної податкової системи з податковим законодавством європейських країн світу. Головною негативною стороною $€$ створення та функціонування незаконних схем щодо ухилення від сплати податків і втрата ініціативи працювати й отримувати більш високий дохід.

Зазначено, що сьогодні у Верховній Раді України на розгляді перебуває Законопроект, який спрямований на запровадження справедливої прогресивної шкали податку на доходи фізичних осіб. Виокремлено основні цілі законопроекту й можливості його втілення в життя.

У результаті дослідження автори доходять висновку, що сучасна податкова система України потребує змін шляхом установлення прогресивного оподаткування для підвищення економічного життя населення.

Ключові слова: система оподаткування, доходи, податок із доходів фізичних осіб, прогресивне оподаткування, прогресивна ставка податку.

It is impossible to provide the economic development of any country without an established tax system. It is the system that plays an important role for the socio-economic development of any state. Nowadays, Ukraine has the tax system with the numerous changes. It is in the Tax Code of Ukraine.

The tax system of Ukraine includes the personal income tax on individuals, which replaced the personal income tax on citizens and which is one of the main taxes that forms the revenues of the country's budget, has the largest number of taxpayers, demonstrates a stable dynamics of revenues. It is well known that choosing a tax policy for personal income, first of all, we must determine its nature: proportional or progressive. And more and more often we can hear about the possibility of introducing in Ukraine such form of taxation as the progressive taxation of personal income. But what constitutes such form of taxation and whether it is appropriate to exist in our country is an open issue to be discussed.

The issues of progressive taxation of personal income were studied by such scientists as: L.M. Demidenko, N.V. Dutova, E.S. Lesik, A.I. Krisovatyi, M.P. Kucheriavenko, V.M. Fedosova, T.D. Datsenko, I.M. Sotnik and others.

The purpose of the article is to determine the nature of progressive taxation of personal income and the possibility of its implementation in Ukraine.

The existence of the tax system in Ukraine dates back to July 1991, when the Law of Ukrainian RSR of 05.07.1991 № 1306XII "On income tax from citizens of the Ukrainian RSR, foreigners and stateless persons" introduced a proportional 
system of taxation of citizens income tax in Ukraine by the citizens of Ukraine, foreigners and stateless persons.

Tax rates started at $12 \%$ and ended at $90 \%$. To speak more precisely, the taxation was as follows: for income at the place of primary employment $-12 \%, 15 \%, 20 \%, 30 \%$; for income, which were defined under this Law in Article $14-2 \%, 3 \%$, $5 \%, 6 \%, 9 \%, 11 \%, 12 \%$; from the sums of authors rewards $2 \%, 3 \%, 5 \%, 6 \%, 9 \%, 11 \%, 12 \%, 15 \%, 20 \%, 30 \%$; to the sums of the rewards to the heirs of the authors repeatedly and decreased by $50 \%$ for the heirs under 18 years and women over 55 and men over $60-60 \%, 65 \%, 70 \%, 75 \%, 80 \%, 85 \%, 90 \%$ [1].

Further, in the period from December 1992 till January 2004, the Decree of the Cabinet of Ministers of Ukraine of 26.12.1992 "Income tax on citizens" (hereinafter the Decree) was in force. Under this Decree, the tax rates were as follows: for income at the place of primary employment $-10 \%$, $20 \%, 35 \%, 50 \%$; no more than $70 \%$ from the sums of authors rewards; for income received from the place of non primary employment $-20 \%$; for dividends on shares and as a result of corporate profit sharing $-15 \%$. As we can see, income that was earned at the place of primary employment was taxed on a clearly progressive scale, and those income that was obtained at the place of non primary employment was taxed at a rate of $20 \%$ [2]

From January 1, 2004 the Law of Ukraine of May 22, 2003 No. 889-IV “On Personal Income Tax" came into force. It abolished the progressive scale of the personal income tax rate. The tax rate was $15 \%$ on income, except the interests on deposits and interest income on saving certificates, on winnings or prizes and other income accrued in favor of nonresidents, etc. [3].

Since December 2010 to the present day the Tax Code of Ukraine has been in force and regulates the taxation of personal income under Chapter IV. According to the Tax Code of Ukraine [4], in our country the tax rate of $18 \%$ of the tax base is applied in respect of the income accrued (paid, provided) (except in the cases specified in paragraph 167.2-167.5 of Art. 167 of the Tax Code), but not exclusively in in the form of salaries, other incentive and compensatory payments or other payments and benefits accrued (paid, provided) to the payer in connection with employment relations and under civil contracts.

The tax system is an essential element of market relations, and it has a big impact on the success of economic transformation in the country. Taxation as a system of relations between the state and the subjects of economic activity - taxpayers influences both the macroeconomic indicators of the development of the national economy and the indicators of economic efficiency and competitiveness of enterprises. There are several basic methods of taxation in the tax system: equal, proportional, progressive, regressive and mixed taxation. First of all, we are interested in progressive taxation. Progressive taxation is a method of taxation when the tax base grows, the tax rate increases. The choice of progressive taxation is based on the determination of discretionary income, i.e free income, the use of which is determined primarily by the payer's interests. Discretionary income is the difference between the total income received by the payer and the non-taxable minimum income [5].

This form of taxation is quite common in the world taxation system. It has been implemented in countries such as Spain, France, Italy, Germany, USA, Netherlands, China, Canada, Japan and others. For example, in Germany traditionally there is a class system of taxation, where the distribution of payers into classes is based on their socio-civic status. There are six tax classes in total; the highest taxes are paid by first class representatives. Income tax in Germany is progressive: income tax rates start at $14 \%$, then rise to $42 \%$ (for incomes above $€ 55,961$ ); finally, a very high level of income (in excess of $€ 265,327$ ) is taxed at $45 \%$. There is a minimum tax rate of $0 \%$. In other words, income of $€ 9,169$ (or $€ 18,338$ for married couples who submit combined income) earned annually is not taxed.

In Italy, depending on the source of income, all incomes are divided into five groups. The income of each group is taxed separately, the rate scale ranges from $23 \%$ to $43 \%$ [6, p. 48].

In Japan, the most significant income to the state budget is brought by income tax. Individuals pay a state income tax on a progressive scale with six rates $-5 \%, 10 \%, 20 \%, 30 \%$, $40 \%$ and $50 \%$. Accrual depends on the amount of the received income. It is paid annually for all types of income received during the calendar year. The minimum rate of $5 \%$ applies to income earned up to 1950000 yen (\$17355).

A progressive income tax scale is set in England - from 0 to $45 \%$. By analogy with the minimum wage, the rates are reviewed annually on April, 1st. Non-taxable income is J $11,500(\$ 15,127)$ per year. This provision does not apply to annual earnings in excess of $\mathrm{J} 123,000$.

Speaking about Canada, we must note that the tax rate in this country starts at $15 \%$ and ends at $29 \%$, in China - from $5 \%$ to $45 \%$, in India - from $10 \%$ to $30 \%$ [7, p. 84$]$.

Having learned how progressive tax rates are set in some countries, one can see that there is a minimum income limit at which taxes begin to be paid. Therefore, in many European countries "the marginal income indicator" has an important place in the tax system. It should also be emphasized that in most countries where a progressive taxation scale is introduced, taxes are paid by prosperous citizens and those who are unable to pay taxes may be exempted. For example, there are five tax rates in Australia. People whose income is less than $\$ 6,000$ a year are tax-exempt. Citizens, whose incomes exceed $\$ 180$ thousand, give $45 \%$ of their income to the state budget. In Canada, taxes are not taxed up to $\$ 10382$. But those who received more than 128000 are obliged to pay $29 \%$ of their earnings to the treasury [8, p. 35].

The Ukrainian tax system provides three privileges to taxpayers on personal income. According to the Tax Code of Ukraine such privileges are: 1) certain types of income are not included in the total monthly (annual) taxable income; 2) tax discount; 3) tax social privilege.

Taxes that are assessed on a progressive system are based on the taxable amount of the individual's income. Progressive tax has more of a financial impact on those with higher incomes than those on low incomes. Therefore, the tax rate, together with the tax liability, increases when an individual is becoming richer. In particular, high-income earners pay more than those who earn less.

Progressive taxation works on the theory that highincome individuals can afford to pay more. Therefore, it can be concluded that such system influences people with higher incomes to ensure the principle of social justice. It should be noted that progressive taxation has its advantages and is justified not only from the point of view of social justice, but also serves as an incentive for the efficient functioning of the economy. By eliminating surplus income from the most prosperous categories of people the state redistributes it to the poor and stimulates overall demand for goods and services, thereby investing in the national economy.

It should be noted that in developed countries, the share of individual income tax in total revenues is much higher than in Ukraine. This is primarily due to the introduction of a proportional rate of income tax, low tax culture of the population and a meager income. After all, the ideology of voluntary payment of taxes has not yet emerged in Ukrainian society, and therefore a large number of taxpayers do not want to recognize such a commitment, do not contribute to the budgets, thus undermining the development and stability of the socio-economic policy of the state. Currently, only a few people recognize the obligation to pay statutory taxes as constitutional [8, p. 34].

The Ukrainian tax system needs to be reformed, in particular the abandonment of the proportional system 
of taxation of citizens' income, since the changes that were made earlier are somewhat outdated. Nowadays, the issue of resumption of progressive taxation of personal income to the tax system of Ukraine has arisen. Taking this fact into account, it would be appropriate to find out the pros and cons of progressive taxation. According to V.M. Kmit, B.B. Grabelsky we can distinguish the following positive aspects: the tax rates depend on the income of individuals that creates normal conditions for taxation; by means of setting progressive tax rates, it will be possible to increase the burden on higher-income payers; progressive taxation has a great power to regulate the economic and social development of regions. The disadvantages are the following: there is a high risk of illegal tax evasion and the difficulty of controlling the correctness of tax calculation; instability of the object of taxation and uneven distribution of tax revenues to different budgets [9, p. 546].

Thus, it can be noted that such a method of taxation is not ideal, but it may be an important step for Ukraine to improve the tax legislation and strengthen our citizens' trust in taxes.

The Verkhovna Rada of Ukraine has registered the bill No. 2758 of January 16, 2020, "On Amendments to Article 167 of the Tax Code of Ukraine (concerning the introduction of a fair progressive scale of personal income tax)" (hereinafter - the bill). According to the Explanatory Note to the bill of Ukraine "On Amendments to the Tax Code of Ukraine (on the introduction of fair progressive taxation of personal income) (hereinafter - Explanatory Note) the purpose of the adoption of this bill is to ensure social justice, reduce the size of the shadow economy, increase the investment attractiveness of Ukraine, slow down the labor migration of Ukrainian workers abroad, and bring the tax rates of personal income in Ukraine to the world average The bill proposes to introduce a progressive scale of taxation of personal income. The explanatory note directly states that for taxpayers receiving a monthly income of no more than the minimum wage (as at the beginning of 2020 - up to UAH 4723 per month), the tax rate will decrease from the current $18 \%$ to $10 \%$.

If the monthly income of taxpayers exceeds the minimum wage but does not exceed 5 times the minimum wage (as at the beginning of 2020 - up to UAH 23615 per month), the tax rate will also be slightly reduced and equal to the minimum wage tax of $15 \%$ of the amount of excess of the tax base over the minimum wage. If the monthly income of taxpayers exceeds 5 times the minimum monthly wage, the tax rate will be equal to the tax of 5 times the minimum wage, plus $20 \%$ of the excess of the tax base more than 5 times the minimum wage.
Thus, as the author of the bill notes, the tax burden will be somewhat reduced for all categories of workers, which will help increase the income of the population after taxation and will create effective economic incentives to unshade the economy of Ukraine in terms of reducing the amount of hidden wages actually paid. Low-paid categories of employees will immediately feel the greatest positive effect [10].

On the one hand, we can see the advantages of adopting this Law. First of all, higher taxes will be imposed on high income earners; taxes will be reduced for vulnerable groups and low-wage workers. For example, poor families spend more of their income on living expenses. They need all the money they earn to buy and pay for such basics as utility bills, food, transportation and teaching children.

The tax reduces their ability to provide a decent standard of living by deducting their income. Of course, introducing such a tax system will greatly reduce their taxes. Progressive taxation improves the purchasing power of the poor. State budget will obtain bigger sums to provide citizens with high quality medicine, education etc.

But, on the other hand, progressive taxation will make people think that getting higher income will cause a lot of taxes and that it won't make sense to work more. This situation is disadvantageous for people who work abroad. It is no secret that many our citizens go abroad to work to earn more and when they return home they will have to pay high taxes. More and more people will try to evade to pay taxes, more and more tax evasion schemes will be created. Therefore, nowadays, we can see both the advantages and disadvantages of progressive taxation of personal income.

Therefore, progressive taxation is a system in which the tax rate increases when taxpayer income increases. Progressive taxation is based on the concept that the taxpayer should pay higher taxes if he or she earns higher income, and lower taxes if he or she earns less. Progressive taxes are a major tool used by countries to reduce income inequality and ensure the principle of social justice in taxation.

In Ukraine progressive tax system had been in force by 2004 , and later it was abolished. As at 2020, the draft law "On Amendments to Article 167 of the Tax Code of Ukraine (concerning the introduction of a fair progressive income tax scale)" has been registered. It aims to change the taxation system to a progressive one, to introduce fairness of taxes. In theory, this proposal has a good chance of being implemented into the economic life of our society but we cannot predict how it will be in practice. However, we are greatly convinced that current tax system needs to be amended, and the adoption of this Law may be the change that is so required for the tax legislation of Ukraine.

\section{REFERENCES}

1. Про прибутковий податок із громадян Української РСР, іноземних громадян та осіб без громадянства : Закон УРСР від 05.07.1991 № 1306-XII. URL: https://zakon.rada.gov.ua/laws/show/1306-12 (дата звернення: 10.03.2020).

2. Прибутковий податок із громадян : Декрет КМУ від 26.12.1992 № 13-92. URL: https://zakon.rada.gov.ua/laws/show/13-92 (дата звернення: 10.03.2020).

3. Про податок із доходів фізичних осіб : Закон України від 22.05. № 889-IV. URL: https://zakon.rada.gov.ua/laws/show/889-15 (дата звернення: 11.03.2020)

4. Податковий кодекс України від 01.01.2011 № 2755-VI. Дата оновлення: 18.03.2020. URL: https://zakon.rada.gov.ua/laws/show/2755-17/ sp:wide\#n3850 (дата звернення: 20.03.2020)

5. Податкове право : навчальний посібник / Г.В. Бех, О.О. Дмитрик, Д.А. Кобильнік, І.Є. Криницький ; за ред. М.П. Кучерявенко. Київ Юрінком Інтер, 2003. 400 c. URL: http://www.info-library.com.ua/books-text-9221.html (дата звернення: 04.03.2020).

6. Дутова Н.В., Лесік Є.С. Оподаткування доходів фізичних осіб в Україні: проблеми та вдосконалення на базі досвіду зарубіжних країн. Економіка і організація управління. 2019. Вип. 1. С. 43-52.

7. Слєпцова Н.В., Кочура Л.В. Зарубіжний досвід оподаткування доходів фізичних осіб та реалії адміністрування ПДФО в Україні. Економіка та держава. 2019. № 4. С. 82-85.

8. Козинець І.Г. Оподаткування доходів фізичних осіб: світовий досвід та вітчизняні реалії. Розвиток наукових досліджень 2013 : матеріали Дев'ятої міжнародної науково-практичної конференції, м. Полтава, 25-27 листопада 2013 р. Полтава : ІнтерГрафіка, 2013. T. 3. C. $34-38$

6. Національна економіка : навчапьний посібник / за заг. ред. О.В. Носової. Київ : Центр учбової пітератури, 2013. 512 c. URL: https:// pidruchniki.com/1207042453171/ekonomika/sistema_opodatkuvannya_ukrayini (дата звернення: 1.03.2020).

9. Кміть В.М., Грабельський Б.Б. Оподаткування доходів фізичних осіб: проблеми та перспективи розвитку в Україні. Східна Європа: економіка, бізнес та управління. 2018. № 17. С. 542-547.

10. Пояснювальна записка до Проекту Закону України «Про внесення змін до Податкового кодексу України (щодо запровадження справедливого прогресивного оподаткування доходів фізичних осіб)» від 06.02.2020 № 2758-1. URL: http://search.ligazakon.ua/l_doc2.nsf/ link1/GI01346A.html (дата звернення: 20.03.2020). 